\title{
European Elections, National Agenda: Facebook in the 2019 Romanian EP Elections
}

Flavia Țăran

ORCID: 0000-0002-7107-5582

BABEȘ-BOLYAI UNIVERSITY, CLUJ-NAPOCA, ROMANIA

Alexandra Catalina Ormenișan

ORCID: 0000-0002-7454-2385

BABESS-BOLYAI UNIVERSITY, CLUJ-NAPOCA, ROMANIA

https://doi.org/10.19195/1899-5101.13.1(25).5

\begin{abstract}
Politicians and political campaigns are not inadvertent to the development of social media platforms as environments that allow access to a larger audience. Not relying solely on the traditional media as a mouthpiece for their messages and taking matters into their own hands offers new segues for analyzing political communication. However, not all elections are of equal interest, both for the electorate and for the candidates, as second-order election theory suggests (Reif \& Schmitt, 1980; Hix \& Marsh, 2004). This paper investigates the area situated at the intersection of these two research directions. This quantitative study aims to analyze how Romanian political parties and candidates used Facebook in the electoral campaign for the European Parliament, in May 2019. The study follows the correlation between Facebook metrics, like frequency of posts and the popularity of the pages, and the political agendas reflected in each party's Facebook posts. The conclusions are consistent with second-order elections theory, but raise questions about the dependable nature of Facebook metrics.
\end{abstract}

KEYWORDS: European Parliament, elections, Romania, Facebook.

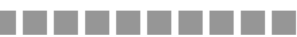

\section{INTRODUCTION}

The spread of the World Wide Web has indisputably left a mark on the way communication is carried out, challenging the established paradigms. Unlike traditional media, which enables a more passive consumption of information, the digital media, especially social network sites, impose a multidirectional flow, allowing users to interact with each other (Himelboim et al., 2012). These technological transformations led to a more powerful and pluralistic debate, but also to 
a better dissemination of the messages, considering that high exposure to this kind of information determines "unprecedented opportunities for communicating with peers about current events" (Jost, Tucker, \& Bonneau, 2015).

According to a local monitoring company, half of Romanians have a Facebook account (9.8 million out of 19.6) (Agerpres, 2019). Corroborating the numbers with the findings of the Hootsuite Digital 2019 report, an overview of the state of social media and its relation to political campaigning can be drawn. The report indicated that Internet use is at $77 \%$ in Romania, with $85 \%$ of people checking the Web every single day, and with 'Facebook' being the most searched term in 2018 (Kemp, 2019). On top of this fruitful social media landscape lies an unhinged political climate, dominated by the tug of war between power (a coalition between the Social Democratic Party - PSD and the Alliance of Liberals and Democrats - ALDE) and opposition (the National Liberal Party - PNL, the centre right 2020 USR-PLUS Alliance), under the scrutiny of small, but vocal parties, like Pro România (founded and led by former prime-minister, Victor Ponta) and PMP (founded and led by former president, Traian Băsescu).

As a response to a slew of proposed modifications to the justice laws and criminal codes, spearheaded by the ruling coalition, the president, Klaus Iohannis, called for a referendum to be organized simultaneously with the EP elections. The referendum inquired about a ban for pardoning and amnesty for corruption convictions, and a ban for Government to make changes to the justice sector through emergency ordinances, circumventing Parliament and the enactment protocols.

The turnout for the European Parliament elections was a record breaking 49.02\% (compared to $32.44 \%$ in 2014 and $39.5 \%$ in the 2016 Parliamentary election). The turnout for the referendum was $41.26 \%$, over the $30 \%$ validation threshold, with 80.9\% "yes" and 13.8\% "no" for the first question (regarding amnesty and pardons for corruption charges), and $81.1 \%$ "yes" and $13.5 \%$ "no" for the second question (regarding government involvement in justice laws and the penal code).

The study goes to continue the tradition of gathering knowledge about the ways Facebook is being used by political actors as an electoral tool. Furthermore, the interest for seeing the agendas of parties in European Parliamentary elections consolidates the current research on the matter. The study also explores the agendas of the parties, through a co-occurrence analysis of the posts. Manual coding and language processing were used to create a network visualization.

\section{STUDIES OF THE EUROPEAN PARLIAMENT ELECTIONS}

According to Hix and Marsh (2007), the European Parliament elections are rather a tool for winning the next national elections than expressing views and ideas concerning EU issues. Their study, covering six rounds of European Parliament elections (from 1979 to 2004) in 25 states, reveals that voters usually use this opportun- 
ity to punish the governing parties. Hence, these become "second-order national contests", being fought in the shadow of those who have a direct influence on forming the government. The same idea is enforced by De Sio, Franklin and Russo (2019), who concluded that every campaign for the EP had a low concern for European matters and focused on national ones instead. They also argue that the 2014 elections were the first to show a heightened interest in European issues. Reif and Schmitt (1980) approached the problematics of second-order elections as early as 1980 , explaining that the main elections are parliamentary or presidential, followed by some regional or municipal ones. Extending their pivotal theory to EP elections has proven fruitful for political communication research.

The low interest generated by these elections may be due to the 'less-at-stake' dimension, as Reif and Schmitt (1980) argued. This implies a lower level of participation, the voters not considering worth investing the effort, an attitude which can also be found among politicians. Furthermore, because of the conviction that they have nothing to lose, voters choose to send their message to politicians by invalidating their vote, to a greater extent than during other elections. Another important aspect is that EP elections represent an opportunity for smaller, newer parties, who do not receive votes in first-order elections, when "more is at stake". This fact was confirmed by Reif and Schmitt (1980) when developing their theory. The small party assertion was applicable in eight of the nine states analyzed.

Governing parties lose voters when they do not meet their economic expectations, which is a part of second-order theory. This effect is more prominent in countries where government alternation is the norm. At the same time, voters are switching preferences in EU elections, considering the policy proposed by parties, which is not a second-order effect (Kousser, 2004). The loss of the elections by the ruling parties was more prominent in 2014, after the economic crisis, which led to a drastic decline of the citizens' confidence in the European Union, reflected in the election result. In 2013, the absolute majority of citizens from 26 European countries considered that their voice did not matter at EU level. Thus, the campaign was dominated by dissatisfaction directed at governments, on a background of the recent economic crisis, but also of an increased number of Eurosceptics (Rafter, 2017, p. 24).

Last but not least, small parties do better in EP elections than large ones, meaning that voters "indulge in the luxury of supporting smaller parties that might seem irrelevant in a national election" (Hix \& Marsh, 2007). This situation rarely happens in Romania, because, for a small party, it is particularly difficult to find a candidate, given the need for 200,000 signatures, previously collected in a certain period. With limited resources, only a few of them can cross the imposed threshold.

One of the main side effects of second-order theory is that the relationship between voters and MEPs is weak, since the electorate was, from the beginning, interested in a domestic agenda, using the vote for punishing parties they were dissatis- 
fied with. Ștefănel pinpoints the Romanian EP paradox, "trust in the EU on the one hand, but lack of interest in EP elections on the other" (Ștefănel, 2016, p. 70), on the rhetoric pushed by the electoral campaigns: domestic issues and national politics.

An overall look at EP elections in Romania reveals that second-order theory was applicable only partially in previous elections. For instance, the first round of elections took place in 2007, right after the country joined the EU. The winner was the Democrat Party (PD), of which Traian Băsescu was a part of, before becoming president. This vote was, most likely, a reward for the achievement of turning Romania into an EU member. In 2014, the Social Democratic Party (PSD), the same party that constituted the government (Victor Ponta of PSD was prime minister at the time), won the elections, in the context of the drastically cut pensions and salaries in 2010, by the liberal-democrats. In 2019, PSD, the governing party, was ranked second, obtaining the lowest score in the party's history $(22.5 \%)$. This was caused by the widespread anger against the social-democrats and their attempts to modify the penal codes to their advantage. At the same time, an observation is necessary: the number of votes for PSD remained the same, compared with the previous EP elections (2,040,765 in 2019 and 2,093,237 in 2014), the percentage difference in the final ranking being given by the high turnout.

\section{SOCIAL MEDIA IN POLITICAL CAMPAIGNS}

Scholars seem to be drawn to the 2008 US presidential campaign as the pivotal point in reviewing the conjunction of social media use in political campaigns. However, more recent research in political communication inculcates the merits of social media as a parallel campaigning tool. Academic interest in this topic has skyrocketed, with a portfolio of research papers covering a spectrum of issues. However, as Stier, Bleier, Lietz and Strohmaier (2018) point out, a significant part of research on Facebook is underrepresented in these social media studies, Twitter being the preferred platform (p. 52). Furthermore, they prompt the question of what is being analyzed, referencing the proclivity for researching the meta-data more often than not, and ignoring the topics discussed.

One of the biggest challenges posed by this type of research is managing the different online audiences (Hoffmann \& Suphan, 2016). Bene (2017) brings into discussion the two-step flow hypothesis, stating that social media content mainly affects a user's friends rather than the users themselves. However, it is difficult to determine whether an additional number of votes is an effect of the two-step flow theory. He also suggests that the Facebook audience oscillates between bounded and fluid, the end result actually being a doubling of the political communication. Bene (2017) also references the effectiveness of campaigning on Facebook as a dynamic between 'preaching to the converted' and 'preaching through the converted'. This top to bottom communication has the potential to infiltrate a large number 
of prospective voters, but the crux of the problem remains the necessity of using Facebook as the central hub of the campaign: is there a direct causal link between the scope of the campaign and election results? In her analysis of party websites and their role in electoral campaigns, Norris (2003) credits the Internet for opening up the field for smaller parties, rendering them more competitive through voicing pluralistic and opposition views. Almost two decades later, the multitude of voices continue to come from the Web, but in a motion of "circumventing the gatekeepers of traditional mass media" (Hoffmann \& Suphan, 2016, p. 3).

\section{INTERACTIVITY AS FEEDBACK}

Previous research on political campaigns looked at rhetoric and language, but in a time when the amount of communication coming out of the campaign was limited to media exposure, flyers, and posters. However, in the context of the 'permanent campaign' prompted by the use of Facebook pages and the sheer quantity of content emerging from these platforms prompts scholars to rethink the research tools. While Bene (2017) looks at the content that triggers reactions, examining Facebook posts, Gerodimos and Justinussen (2015) consider the social buttons on Facebook as tools for voicing political preferences.

Of course, since many of these studies were published, Facebook introduced, in February 2016, the reactions suite, to accompany the elusive 'like' button, in an attempt to nuance the way users interact with posts (Stinson, 2016). The cited WIRED article details the decision-making process behind the reactions, reporting that "Facebook decided to focus on the sentiments its users expressed most often". By this logic, the reactions chosen were Love, HaHa, Wow, Sad, and Angry. Nonetheless, even if the options for engaging with Facebook content has gone up, the reactions still seem elusive, especially in a political communication context: are the Angry reactions attributed to the candidate or the infuriating thing she shared? Within these limitations, it is hard to pinpoint the reasons behind pressing the 'like' button, but previous studies prove that "the number of 'likes' implies exposure, attention, and some sort of affirmation, ratification, or endorsement of what is posted" (Gerodimos \& Justinussen, 2015, p. 118). Therefore, it is futile to read too much into the meanings and justifications of post reactions.

While the Web was initially expected to facilitate more direct communication and interaction between politicians and their voters, it turned out that elected officials and candidates use digital media for top-down communication in an information-centric way. The communication avoidance is due to "the lack of resources, the fear of losing control over the message and the chance of ambiguity" (Bene, 2017). Bene's study, focused on the 2014 Hungarian general elections, shows that for effective political communication on Facebook, interactivity must be achieved, by triggering reactions. 


\section{RESEARCH DESIGN}

The aim of this research is to extract knowledge about how Facebook was used by political groups and candidates in the 2019 European Parliament elections in Romania, a country of both high-speed Internet and top use of social media, but also with almost $50 \%$ of its inhabitants living in rural areas. Political campaigns in the age of Facebook still require methodological troubleshooting. In the context of trolls, armies of posters and pay-per-likes, even the most straightforward of metrics can derail analysis and subsequent observations. The research interest covers not only how the campaign communicated, but also what kind of information was disseminated on the platform.

This research sets out to answer the following questions:

RQ1: What types of content were used on the Facebook pages of politicians and parties during the European Parliamentary election in Romania? RQ2: Which candidates and parties conducted the most intense campaign on Facebook, according to the frequency of the posts?

RQ3: Can Facebook metrics reflect a coherent record for the popularity of the pages?

RQ4: What were the main subjects on the political agenda for the European Elections?

\section{METHODOLOGY}

Research on Facebook metrics favors a quantitative approach. The literature on the subject still considers that reading too much into a comment or a reaction can hinder the retrieval of clear results. The interaction with a Facebook post (through reactions, comments, or shares) can be perceived as an indicator of a successful communication act in an interactional model, which allows for feedback even in instances of mass communication.

Both how and what questions posed earlier can be answered using quantitative data collected from political pages. How the campaigns communicated can be illustrated by metrics like social buttons, page likes, and number of posts made by each page. What the campaigns communicated can be visualized looking at word frequencies and co-occurrences. The sampling of the data needed to be based on the election results. As shown in Table 1, six parties made the 5\% threshold for entering the European Parliament, covering the core of the sample. Due to the language barrier, the Democratic Alliance of Hungarians in Romania (UDMR) was excluded from the sample. The Alliance of Liberals and Democrats (ALDE) performed poorly in the elections, even though it was a governing party at the time, in a coalition with PSD. However, given its place in the political landscape, ALDE was also included in the study. 
Table 1. Results of the European Parliamentary elections

\begin{tabular}{|c|c|c|c|}
\hline \multicolumn{2}{|r|}{ Party/Candidate } & \multirow{2}{*}{$\begin{array}{c}\text { Doctrine/Affiliation } \\
\text { conservative-liberal }\end{array}$} & \multirow{2}{*}{$\begin{array}{c}\begin{array}{c}\text { Election } \\
\text { results (\%) }\end{array} \\
27\end{array}$} \\
\hline PNL & National Liberal Party & & \\
\hline PSD & Social Democratic Party & social-democratic & 22.51 \\
\hline $\begin{array}{l}\text { Alianța } 2020 \\
\text { USR PLUS }\end{array}$ & $\begin{array}{c}\text { URS - Save Romania Union } \\
\text { PLUS - Freedom, Unity and } \\
\text { Solidarity Party }\end{array}$ & centre, centre-right & 22.36 \\
\hline $\begin{array}{c}\text { PRO } \\
\text { România }\end{array}$ & & social-liberal & 6.44 \\
\hline PMP & People's Movement Party & centre-right & 5.76 \\
\hline UDMR & $\begin{array}{l}\text { Democratic Alliance of } \\
\text { Hungarians in Romania }\end{array}$ & Hungarian minority & 5.26 \\
\hline ALDE & $\begin{array}{c}\text { Alliance of Liberals and } \\
\text { Democrats }\end{array}$ & liberal & 4.11 \\
\hline UNPR & $\begin{array}{l}\text { National Union for the Progress } \\
\text { of Romania }\end{array}$ & social-democratic & 0.60 \\
\hline PRODEMO & $\begin{array}{c}\text { The Alternative for National } \\
\text { Dignity }\end{array}$ & pro-European & 0.58 \\
\hline PRU & United Romania Party & national conservatism & 0.57 \\
\hline PSR & Romanian Socialist Party & socialism & 0.44 \\
\hline PSDI & $\begin{array}{c}\text { Independent Social Democratic } \\
\text { Party }\end{array}$ & social-democratic & 0.29 \\
\hline BUN & National Unity Block & coalition of civic associations & 0.22 \\
\hline \multicolumn{2}{|c|}{ Tudoran Georgiana-Carmen } & independent & 1.10 \\
\hline \multicolumn{2}{|c|}{ Simion George-Nicolae } & independent & 1.29 \\
\hline \multicolumn{2}{|r|}{ Costea Peter } & independent & 1.44 \\
\hline
\end{tabular}

Source: Authors.

The final sample was comprised of five parties and an alliance, their respective leaders and the top three candidates on the ballot for each party. As detailed in Table 2, jumps were made where the party leader was also a candidate or when the candidate was lacking a Facebook page. 
Table 2. Sample - Candidates

\begin{tabular}{|c|c|c|}
\hline PSD & PNL & 2020 URS PLUS Alliance \\
\hline $\begin{array}{l}\text { Rovana Plumb } \\
\text { Carmen Avram } \\
\text { Claudiu Manda }\end{array}$ & $\begin{array}{c}\text { Rareș Bogdan } \\
\text { Mircea Hava } \\
\text { Siegfried Mureșan }\end{array}$ & $\begin{array}{c}\text { Dacian Cioloș (party leader) } \\
\text { Cristian Ghinea } \\
\text { Dragos Pislaru } \\
\text { Clotilde Armand }\end{array}$ \\
\hline ALDE & Pro România & PMP \\
\hline $\begin{array}{c}\text { Norica Nicolai } \\
\text { Daniel Barbu } \\
\text { Renate Weber (no Facebook } \\
\text { page) } \\
\text { Ovidiu Silaghi (no Facebook } \\
\text { page) } \\
\text { Varujan Vosganian }\end{array}$ & $\begin{array}{c}\text { Victor Ponta (party } \\
\text { leader) } \\
\text { Corina Crețu } \\
\text { Mihai Tudose } \\
\text { Iurie Leancă }\end{array}$ & $\begin{array}{l}\text { Traian Băsescu (party leader) } \\
\text { Eugen Tomac } \\
\text { Ioana Constantin (no Facebook } \\
\text { page) } \\
\text { Marius Paşcan } \\
\text { Simona Vlădica }\end{array}$ \\
\hline
\end{tabular}

Source: Authors.

\section{DATA COLLECTION}

The data collection process was initiated on June 28th and covered four time segments: S1 pre-campaign (April 25th-26th), S2 campaign (April 27th-May 25th), S3 Election Day (May 26th) and S4 post-election (May 27th-28th). The work datasets were DS1 = 31 Facebook pages (see the Appendix section for details) and DS2 = 2941 posts. The data was collected using Facepager, a Facebook API interrogation tool. The following information was retrieved for each post: message, created time, type of post, number of shares, comments, likes, and reactions (Love, Wow, $\mathrm{HaHa}$, Sad, and Angry). DS1 includes metrics proper to Facebook pages: page likes, the date when the page was created, number of posts (total and per time segments).

Bene (2017) suggests the existence of a control variable in his research on Hungarian Facebook pages during the general elections, proposing either the number of followers (page likes) or a weighted average activity score, where all social buttons are seen as equal, obtained using the following formula:

$$
\begin{aligned}
& \underline{x} *\left(\frac{1}{x_{w} * 100}\right)+\underline{y} *\left(\frac{1}{y_{w} * 100}\right)+\underline{z} *\left(\frac{1}{z_{w} * 100}\right) \\
& \underline{x}=\text { average reactions, } \underline{y}=\text { average comments, } \underline{z}=\text { average shares } \\
& x_{w}=\frac{\underline{x}}{\underline{x}+\underline{y}+\underline{z}}, y_{w}=\frac{\underline{y}}{\underline{x}+\underline{y}+\underline{z}}, z_{w}=\frac{\underline{z}}{\underline{x}+\underline{y}+\underline{z}} \text { are the weights }
\end{aligned}
$$

For the purpose of this research, both the page likes and the popularity scored were added to DS1, posing a methodological dispute which will be addressed in the article. 


\section{LIMITATIONS AND ADVANTAGES}

Quantitative analysis on Facebook pages and posts pose several limitations, like the retroactive nature of the data collection process, the nuanced quality of social button usage, the elemental issue of the 'permanent campaign', and the many uses of the Facebook page (for example, page likes are irrefutably hard to explain when analyzing a short time span in the life of a page). Regarding the actual messages posted, the underlying issue is that one does not always know who the author of a post is - the politician, a campaign staffer or both - leaving room for a fragmented campaign communication.

Given that the analyzed texts were in Romanian, some subtle language specificities might have been lost in translation. This limitation has also been addressed in the text analysis. The exclusion of troublemaking concepts was a methodological choice thought not to hinder the integrity of the analysis, while still covering enough of the dataset.

Favoring a quantitative approach in text analysis offers a series of advantages: it is time-efficient, it cuts out human interactions with the texts, which can lead to misinterpretations, and it offers structured knowledge about large bodies of texts. The general rule of thumb used in this research paper was that an analysis on Facebook data must oscillate on a spectrum between near and far: not too near and granular as to read too much into the texts and reactions to the texts, but not too far as not to grasp the intentions of the communication. The present quantitative methodology was constructed to adhere to this self-imposed system.

\section{FINDINGS}

The present analysis is based on the two datasets, detailed in the previous section: DS1 containing the Facebook pages and DS2 containing the posts. These provide quantitative evidence for using Facebook as an electoral campaigning tool. The second part of the analysis was based on the texts of the posts, used to create structured knowledge about the contents of the communication.

\section{Facebook metrics}

Looking at page likes, number of posts, and page popularity offers limited insight into the way Facebook metrics can quantify a campaign effort. Considering, as Bene proposes, either the number of page likes (which must reiterate the retrospective nature of data collection) or the weighted average activity score as control variables, can render flawed results.

For most of the PSD-related pages, the page likes and the popularity scores are unbalanced. Given that it was based on the averages of social buttons, the popular- 
ity score favors fewer posts, but with more activity, this being the case of Liviu Dragnea, for example. PNL is the leader by number of posts, but they are directed to small audiences and thus experience little interactivity. In the case of the newlyformed 2020 Alliance, former technocrat prime-minister Dacian Cioloș stands out both by number of page likes and the highest popularity score, again, in the context of a moderate number of posts. The situation at hand required the data to be scaled in a manner that would allow for comparison. The highest value from each data slice was awarded a score of 100 , and the remainder were calculated proportionally (Figures 1, 2, and 3).

Scaling the three metrics in this way allows for clearer interpretations. Campaigning on Facebook presents itself as a double-edged sword: neither the number of posts, nor the number of page likes can guarantee interactions with the messages (this is apparent if looking at PNL and Victor Ponta). The metrics show no direct correlation between the three metrics analyzed - number of post, page likes and page popularity.

Interactivity is a more nuanced practice and it seems to have little to do with the other metrics. ALDE has a modest presence, but not the lowest (even though one of its candidates, Varujan Vosganian, had zero posts in the analyzed time frame), but it was one of the parties that did not enter the EP. Also, flooding a page with posts is a practice that does not guarantee interactivity, as the PNL metrics show (Figure 4).

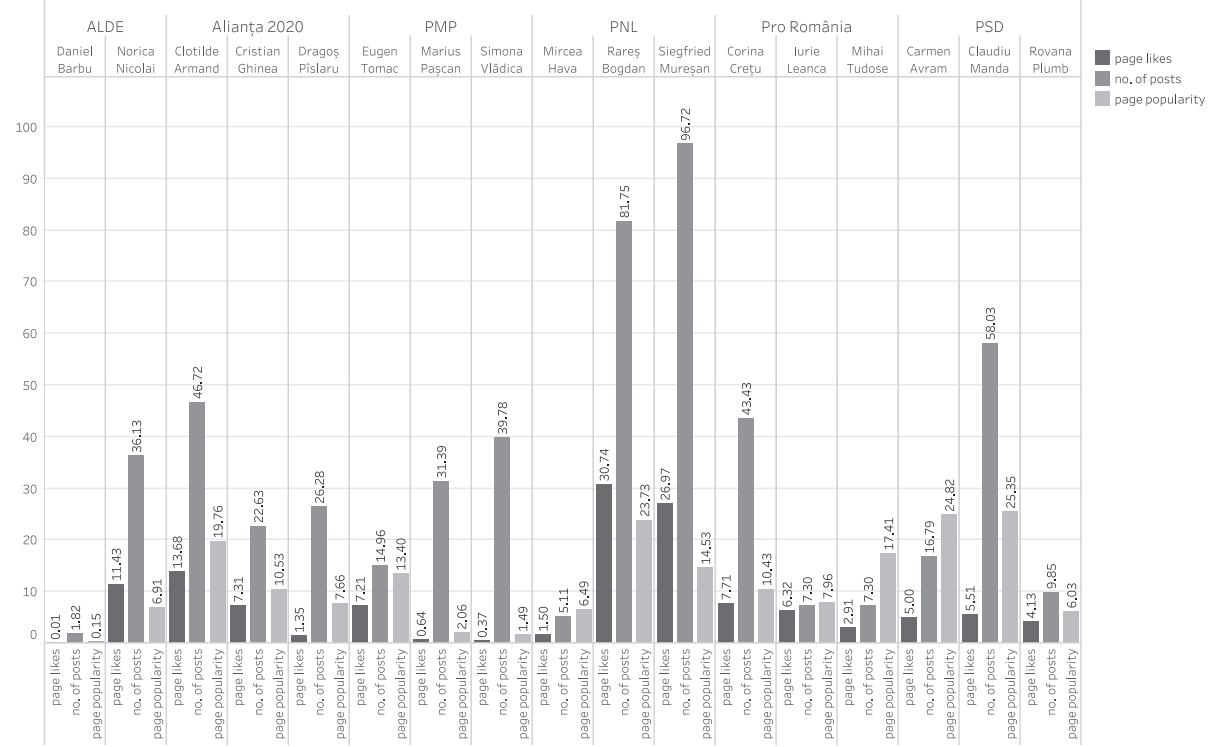

Figure 1. Scores for the candidate pages

Source: Authors. 


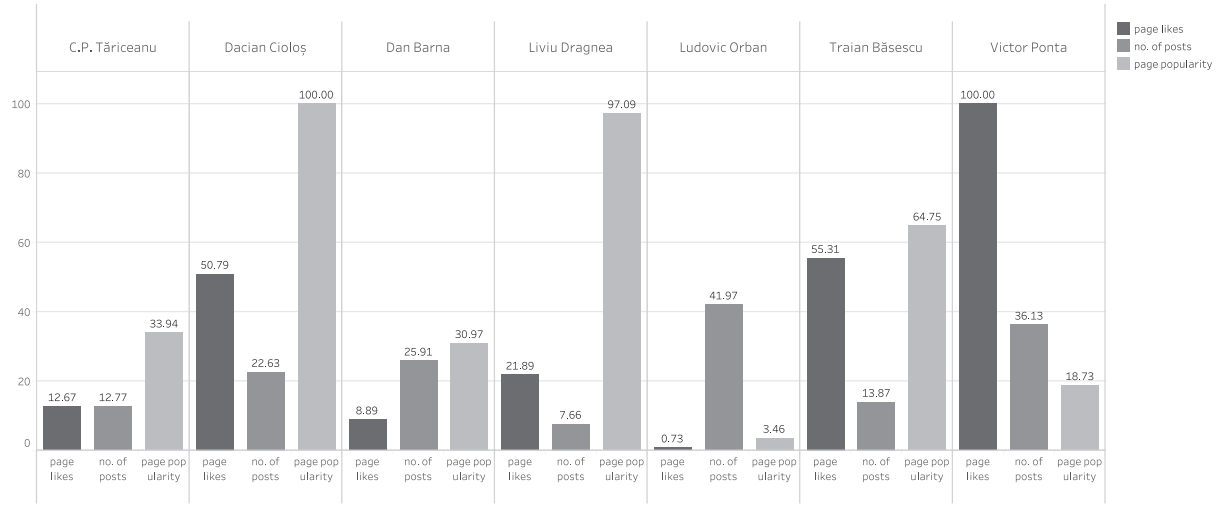

Figure 2. Scores for the party leader pages

Source: Authors.

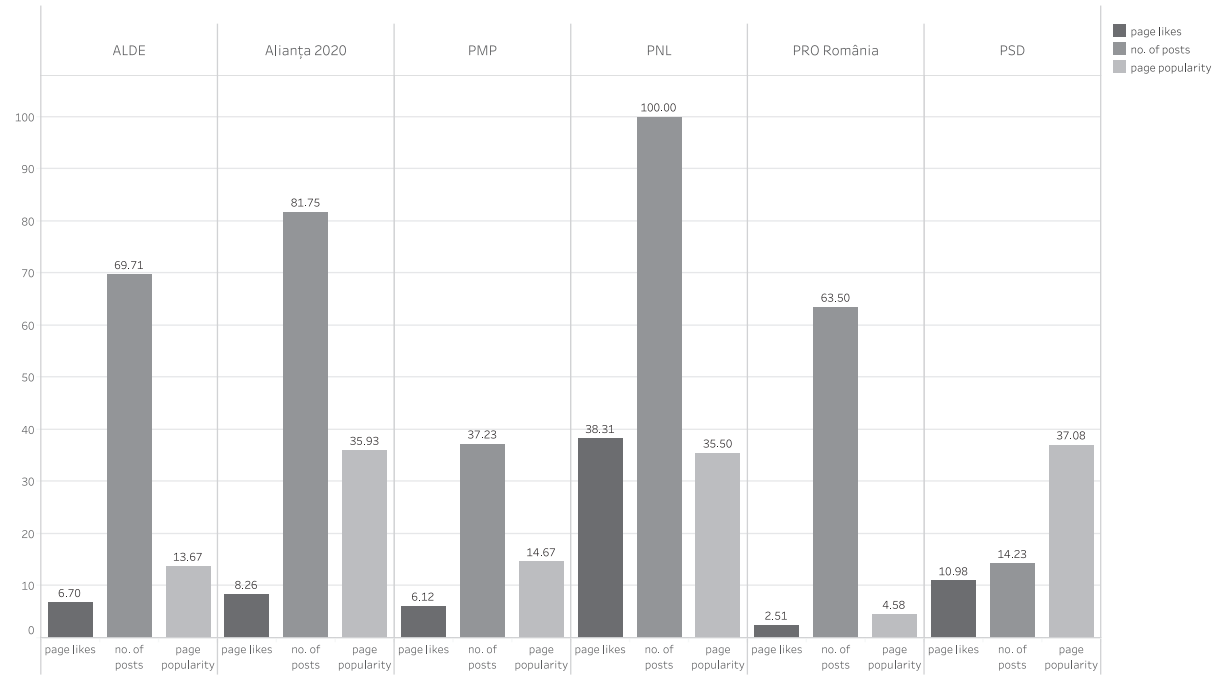

Figure 3. Scores for the party pages

Source: Authors. 


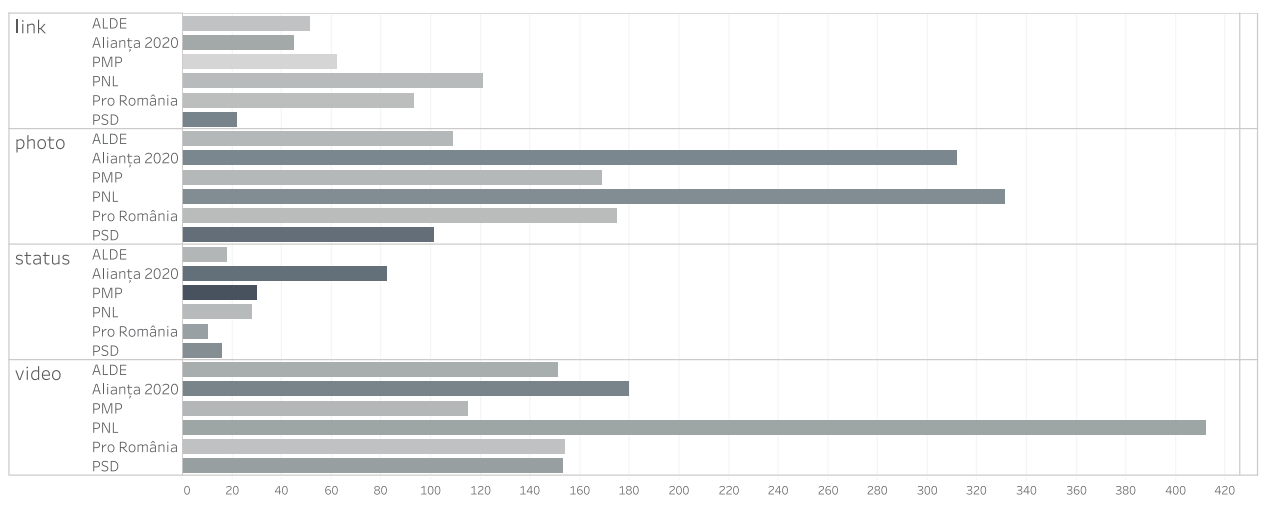

Figure 4. Number of posts according to type, clustered by affiliation. The gradient indicates the total value of social interactions (reactions, shares, comments)

Source: Authors.

The prevalence for visual content is evident in Figure 4, with all parties preferring to post videos and images. Posting statuses, which usually entails blocks of text, is an undesirable practice from a campaign standpoint. However, this taxonomy of post types can be ambiguous. Table 3 offers an overview of text length for each post type (the average was calculated excluding posts with no text). Videos and photos were usually accompanied by text, making political messages on Facebook, more often than not, multimodal (text + image, text + video), despite being circumscribed in a specific post category.

Table 3. Breakdown of text length for each type of post

\begin{tabular}{|l|c|c|c|}
\hline Post type & No. & \% of text & Average length (characters) \\
\hline Link & 394 & 69.0 & 454.06 \\
\hline photo & 1197 & 93.4 & 589.98 \\
\hline status & 184 & 98.9 & 674.18 \\
\hline video & 1165 & 75.3 & 395.11 \\
\hline
\end{tabular}

Source: Authors.

The data shows a sizeable number of videos posted by PNL, but also a spike in activity on election day (Figure 5). The European Parliament election law (33/2007) prohibits electoral propaganda after the end of the allotted campaign period. However, the law is 12 years old and does not cover the online dissemination of information during election day. $42 \%$ of the posts made by PNL (116) were posted on 
election day. With an average of 7 posts/hour (between 0700 and 2300), the PNL campaign flooded its audience with videos (61) and photos (55) showcasing queues from polling stations from across Europe. Even though this kind of behavior does not fall under the incidence of the election law referenced earlier, it is intended to discredit the organizers of the diaspora elections, the governing parties, in an anticampaign manner.

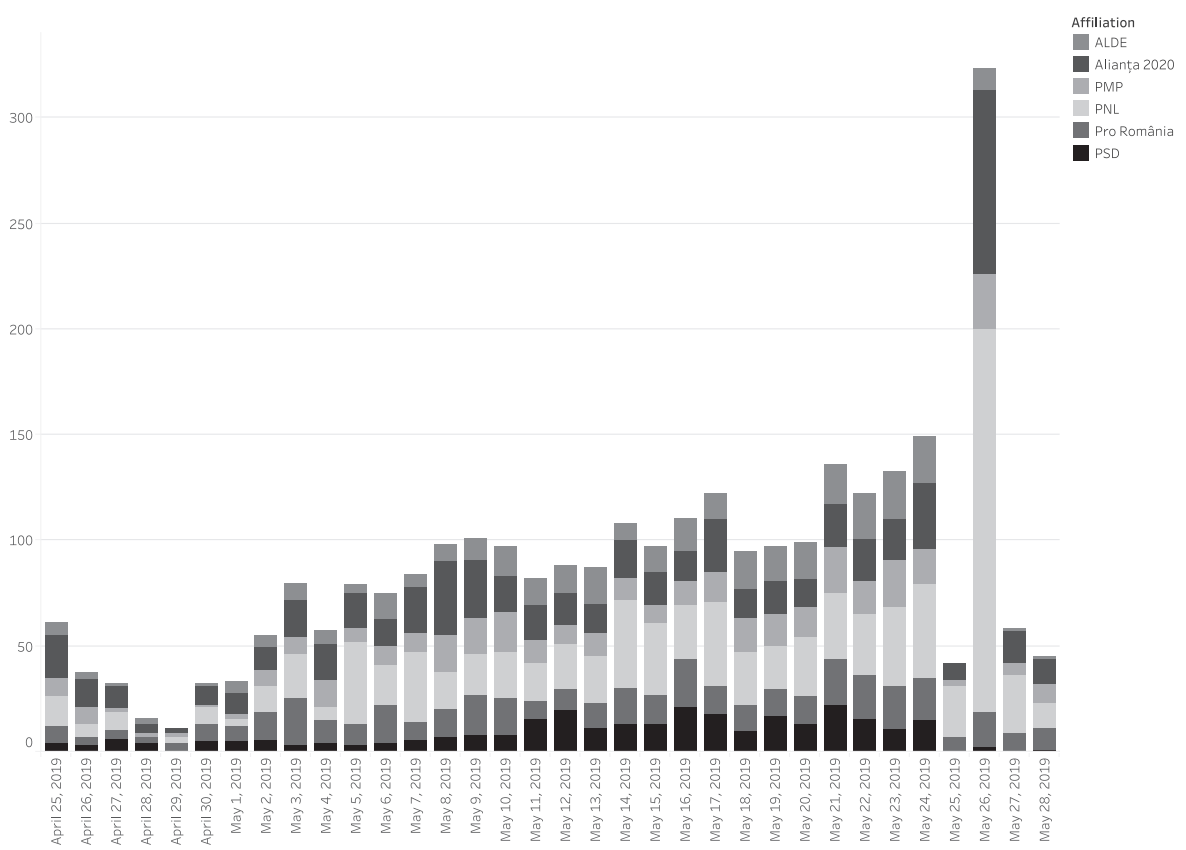

Figure 5. Timeline of number of posts and affiliation of pages DS2 $=2941$

Source: Authors.

On election day, only two posts came from PSD-affiliated pages (Manda's statement after exiting the polling station and Plumb thanking voters), followed by radio silence from party officials. A solitary message comes on May 27th from senator and candidate Claudiu Manda, who thanks the people of his constituency.

As previously stated, reactions must be interpreted within certain limits, as they could be misleading. However, a trend can be seen in Figure 6: Love, Angry, and $\mathrm{HaHa}$ roughly follow this order for four out of the six parties analyzed. ALDE and PSD offer two different layouts: ALDE is seeing little Love, while PSD leads with HaHas. These findings are consistent with the Romanian Institute for Evaluation and Strategy (IRES, 2019) post-election voting profiles: ALDE and PSD do not have a consolidated following amongst young and urban voters, most likely Facebook users. Political campaigning on Facebook can be derailed by opposition 
voters in the democratic structure of social media, making ALDE and PSD posts targets for interpretation-prone reactions.

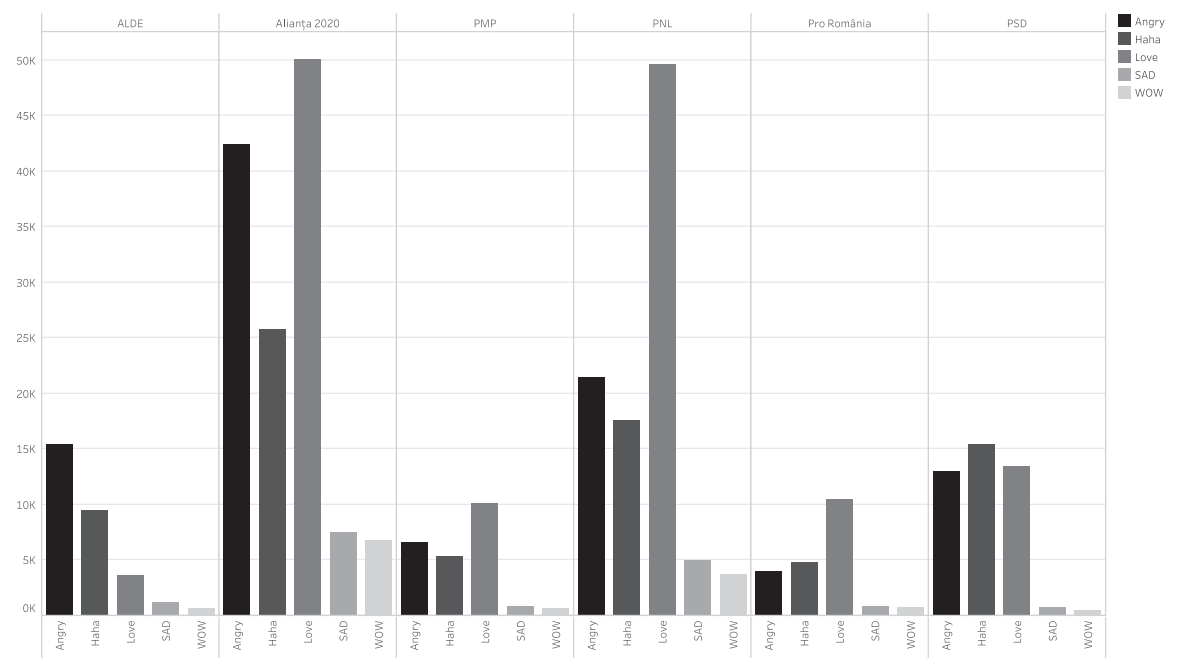

Figure 6. Reactions (other than Like) according to page affiliation

Source: Authors.

The valences of reactions are manifold and require more granular analysis to be correctly understood. However, for the purposes of this analysis they display consistency for parties shown to be more present on Facebook in the timeframe analyzed. For PSD and ALDE, the campaign was not fought on Facebook, as shown by the metrics presented earlier, but on different fields, also given their position as the governing coalition.

\section{Posts analysis}

The quantitative analysis of posts was done with $\mathrm{KH}$ Coder, an open-source software used for text mining and content analysis. The software was not designed for Romanian texts, but it can operate with them. Based on a word frequency chart, manual coding was used to cluster words, both by subject (e.g. agriculture code contained agriculture, farmer, field) and semantics (e.g. to_change contained all the forms of the verb). Stop words were filtered out on the basis of commonality and ambiguity, while the forced pick up function was applied for names, institutions and similar constructions (e.g. Liviu + Dragnea, European + Parliament).

KH Coder "draws network diagrams that show the words with similar appearance patterns, i.e. with high degrees of co-occurrence, connected by lines (edges)" (Higuchi, 2016, p. 50). The display algorithm used for this visualization was the 
Jaccard coefficient, calculated for all possible word combinations and used as a reference to draw the graph's edges.

In this analysis, the edges were drawn between codes and an independent variable, the party affiliation, in order to create thematic clusters for each party campaign. Based on the Jaccard coefficient, the top 100 edges were featured in the visualization. The colour indicates the degree (the number of edges connecting the vertices) and the size of the vertices indicated the number of words in the code.

Before rendering the visualization (Figure 7), further codes were eliminated, due to their perceived vagueness and translation ambiguity. Substantial codes, by number, but with little to say about the campaign (i.e. Romania, country, people, voting, politics, European) and very generic verbs (to say, to do, to want, to see) were also filtered out, favoring a more detailed look at the topics tackled by each party.

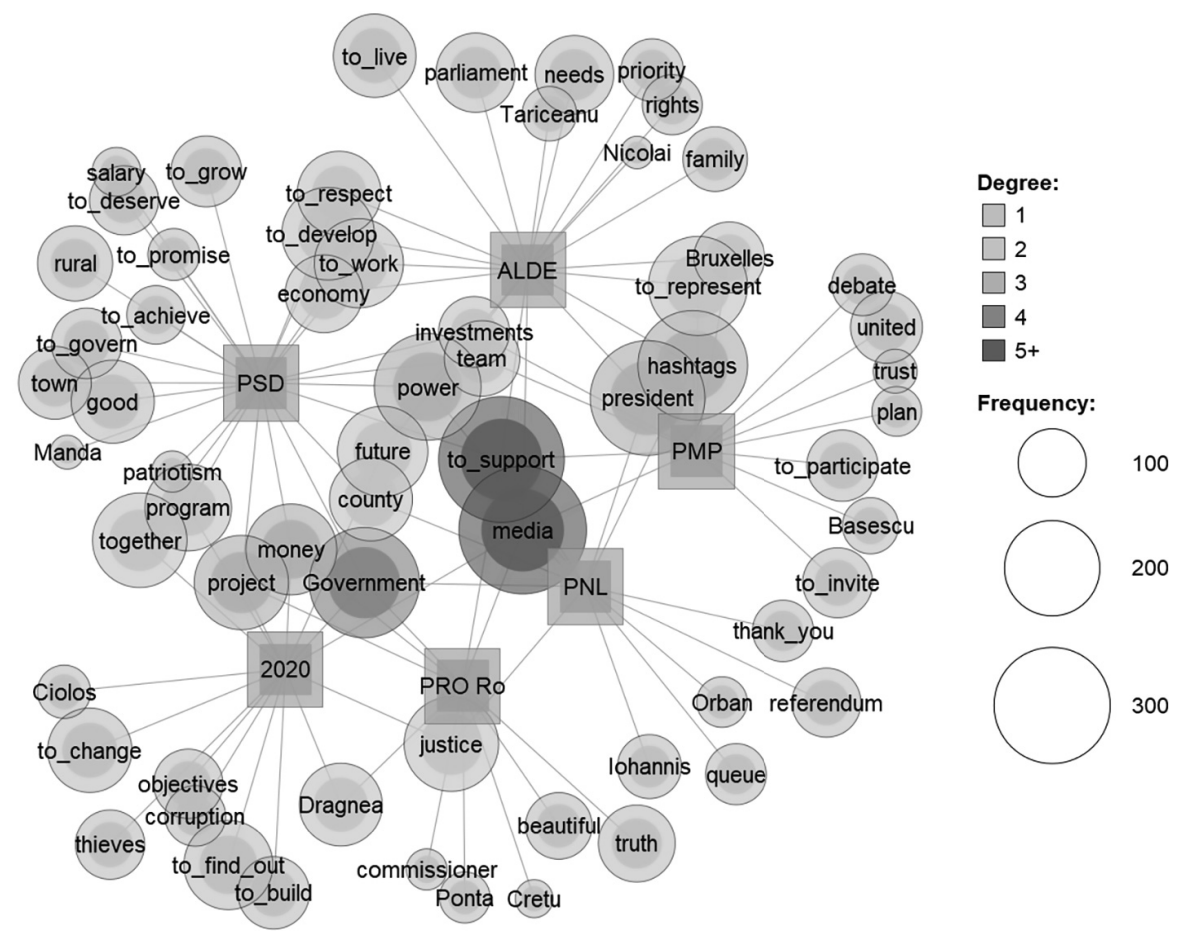

Figure 7. Co-occurrence network with top 100 edged by Jaccard coefficient and party variable vertices (DS2 $=2941$ Facebook posts)

Source: Authors.

A text analysis cannot be reduced to a visualization, but this methodological enterprise has the potential to cut through the noise and outline the major campaign interests seeping through the Facebook pages. Figure 7 offers an overview of a corpus of text without falling short by interpreting meaning and rationale, as a rhetor- 
ical analysis might do. The quantitative analysis reveals that the two governing parties, PSD and ALDE, focused on their achievements: salaries, development, investments, or economic growth. This indicates they used their government work for campaigning, although the national issues raised did not concern Europe.

A couple of other numbers are required to visualize the prerequisites for understanding some of the concerns posed in the co-occurrence network. According to the 2011 census, $44.8 \%$ of the population lived in rural areas. Recent years have shown an increase in Internet connections in rural areas, with 1.6 million rural households having an Internet connection in 2019.

The Social Democrat Party constructed its previous campaigns on the idea of patriotism, with slogans like "Proud to be Romanian". This is something that also seeps into the Facebook messages, upholding the idea of sending patriots in the EP, in order to represent Romania properly. The social-democrats try to appeal to rural voters, pushing a strong agenda that should interest half the country. It remains, however, unsure to what extent these messages reach their target audiences. Compared to other campaigns, they ground their message in palpable and visible subjects, as opposed to abstract notions like corruption, justice and truth.

In PNL posts, frequent references to President Klaus Iohannis and the referendum can be found, which shows the party's support for the president's initiative. Criticism towards the Government and its meddling in the justice system are key subjects. The presence of queue is not surprising, given that half of the PNL posts were made on election day, on the subject of queues in the diaspora polling stations. The PNL cluster shows limited interest topics, highlighting some core agendas: the referendum, the diaspora elections and the endless queues, and the government. Surpassing PSD in any type of elections was met with gratitude, as shown by the thank you code.

The intensive anti-government campaign is visible in the Pro România and 2020 Alliance messages as well, the two parties sharing interest in the Government, Liviu Dragnea and the justice system. Dragnea becomes a key figure in the rhetoric, even though he is neither a candidate, nor part of the Government, being framed as an adversary in campaigns focusing on the rule of law agenda.

Although the 2020 USR-PLUS Alliance focused on justice, corruption and thieves (they are also the authors of an initiative to amend the Constitution, by which people with convictions cannot be elected to public functions), they did not run a campaign for the referendum initiated by President Klaus Iohannis. Former prime minister Dacian Cioloș is a prominent talking point, alongside change, projects, objectives, and construction of a new society.

PMP is the party that focused the most on European issues. From the posts on Facebook, items like debate, investments, participation, or unity stand out. Together with ALDE, they share a common discourse on representation in Brussels, and an affinity for using hashtags in their posts.

As a general conclusion, the Government was the main focus of four of the parties, one of them using it for showing their achievements (PSD) and the others for 
running an anti-campaign against PSD, their main opponent (PNL, Pro România, and 2020 Alliance).

One of the most frequent topics touched by all parties is the media. This can be explained by the bridge created by candidates between old and new media, announcing TV appearances on Facebook. Also, candidates cite traditional media when criticizing the statements made by other candidates. National television is a prominent talking point, being criticized for showing support towards PSD.

\section{DISCUSSION}

The strict election laws of Romania (TV is off-limits, posters must be displayed in pre-selected locations, all print commercials are coded and supervised) push the parties and politicians to embrace the freedom offered by social media, this no man's land of unregulated political campaigning. In this context, Facebook does not serve as a parallel tool, but as the tool to rule them all. Both legacy and small parties found their voice on Facebook during the EP elections, disseminating a plethora of content, but mostly audio-video.

Not surprisingly, most of the posts had a visual component, photo or video, doubled by text. The study revealed that multimedia content produced more engagement, being reminiscent of the ways of traditional media. Text posts, rare as they were, underperformed from an engagement standpoint.

In terms of popularity, the main finding of this study is that it is neither guaranteed by a large number of followers nor by a high number of posts. The literature suggested that audiences are hard to delineate in online networked environments, so straightforward metrics like number of page likes or number of posts cannot be correctly translated into "popularity" as a result of the audiences' interaction with the political content. For example, the most active candidate, Siegfried Mureșan, is far from being one of the most popular. This is also the case of Victor Ponta, who, despite the highest number of followers, has a low degree of popularity.

The metrics highlight that the effort invested in campaigning on Facebook is a hit-and-miss tactic. The parties have constantly communicated on their Facebook pages during the EP campaign, with the biggest opposition party in the country and the one with the most at stake, PNL, being the most active. This is consistent with what the literature suggests about identifying the stakes of the game and strategising accordingly.

The aggressive campaign carried out by the Liberal Party is justified by the multitude of messages that they wanted to send to the public. The main campaign was for the European Parliamentary elections, doubled by a referendum campaign, and flanked by an anti-government sentiment. It was, therefore, a triple campaign that PNL wanted to manage, so the party disseminated information threefold, given the nature of its audience on Facebook. On election day, PNL used Facebook to highlight the incapability of the Government to organize civilised elections for its dias- 
pora. The frequent posts had the role, apart from signalling these irregularities, to discredit the main counter-candidates. This is a less intuitive finding, but which comes to highlight a domestic problem with elections that has been going on in Romania for years.

The 2020 Alliance carried out a very active online campaign, due to its younger audience, more reachable online (IRES, 2019). A derivate finding of this study identifies the strategy employed by the 2020 Alliance. Given its status as a newly- formed political actor, the coherence of the message is important. The metrics show that the candidates had a very feeble presence on their personal pages, while the party page engaged in constant posting.

The biggest party in Romania, PSD, had a disproportionate online presence. This tactical decision is supported by the Romanian Institute for Evaluation and Strategy survey (2019): the PSD constituency is much older and more responsive to traditional media. Thus, the social democrats did not need an aggressive online campaign, given the fact that their electorate received information from other sources.

As the analysis of the political agenda on Facebook shows, the governing parties used the campaign to highlight the government's achievements over the past three years, reiterating the increasing salaries and pensions, economic growth, and tax cuts. On the other hand, the main ideas expressed by the opposition parties concerned the mistakes made by the government, such as remuneration increases without an economic base, false economic growth, repeated attempts to modify the criminal codes, but also the fiscality, which negatively affected the business sector.

The prevalence of domestic issues in this EP campaign is consistent with secondorder theory. As other researchers have concluded in previous studies (Hix \& Marsh, 2007; De Sio, Franklin \& Russo, 2019), the election campaign for the European Parliament is more about national issues and less about European problems, especially when these elections precede the national ones. In Romania, the EP election was followed by the presidential one (in November 2019) and the local and parliamentary ones (in 2020), and the discourse of each party and candidate, through Facebook posts, reveals that the whole campaign was focused on internal political games.

The analysis on the uses of Facebook highlights the idea that the European Parliamentary elections are second-order national contests, in which parties actually campaign for the forthcoming national elections. Also, EP voting is used by the electorate to sanction the ruling parties, but in the case of Romania, this happened atypically: PSD-ALDE were punished by the electorate with a massive turnout.

\section{CONCLUSIONS}

From a theoretical standpoint, the present study was based on three pillars: secondorder theory, the uses and abuses of Facebook as a campaigning tool, and the limitation of social media meta-data as an analysis metric. Empirically, the study spans 
beyond the elusive likes and shares, and proposes new avenues for scrutinizing political communication on social media, by introducing a control variable that ties the meta-data together, but also by incorporating an analysis of the text corpus posted on social media.

The EP campaign in Romania relied heavily on the use of social media, with a grand total of 2,941 post spanning 31 Facebook pages. Our research interests were directed towards recounting this election campaign in the context of political unrest in Romania and the approaching presidential election in November of 2019.

The social media analysis revealed new facets of the issue of content: multimodal communication is made easy by social media platforms, and considering that "seeing is believing", much of the content is comprised of visual aids (video and photo), accompanied by text and captions. Solo text posts received little engagement compared to multimodal ones, however, the retrieved text corpus was consistent enough for a topical quantitative analysis.

Considering the main political parties from Romania and their place on the political scene, the intensity of their campaigns follows a curious distribution, consistent with what is at stake: PNL spearheaded several campaigns in one: for the president's re-election, for the referendum, for the EP, and an anti-government one. The runner-up, the 2020 Alliance, rode on the wave of dissatisfaction with the current political class and tried offering an alternative, while the largest party in the country, PSD, had a less intense campaign on social media, having other alternatives, as the governing party.

From a methodological standpoint, the very volatile nature of the metrics raises new and troubling questions about the usefulness of control variables in this type of quantitative analysis. The page likes and the weighted popularity scores are incongruent and offer very different readings of the metrics. This is a noteworthy finding that can be translated into actionable information by politicians and campaign coordinators.

The topics tackled by all the parties are mostly outside the scope of the European Union, covering domestic issues, the political unrest and its alleged architect, Liviu Dragnea. Each party addressed key issues, but related to internal affairs: economic wealth (PSD and ALDE), anti-corruption (2020 Alliance and Pro România), the referendum (PNL).

Our findings are consistent with Ștefănel's analysis of the 2014 EP elections reflected by the television news media: a dress rehearsal for the upcoming presidential elections and an opportunity for the parties to test their strategies and set out their battle lines (Ștefănel, 2016, p. 78). Facebook and online campaigning are currently outside the incidence of the election law, but given the volatility of this communication channel and the still unquantifiable impact that it has on voters, revisiting the law becomes a problem that needs addressing at the state level. One of the more troublesome findings of this research is the aggressive posting from election day, which lies, for the moment, in the grey area of current laws. 


\section{REFERENCES}

Agerpres (2019, January 29). Aproape zece milioane de utilizatori Facebook în România. Euractiv.ro. Retrieved February 2, 2020, from https://www.euractiv.ro/infosociety/aproape-zece-milioanede-utilizatori-facebook-in-romania-13323 adresinden alındı.

Bene, M. (2017). Go viral on Facebook! Interactions between candidates and followers on Facebook during the Hungarian general election campaign of 2014. Information, Communication \& Society, 20(4), 513-529.

Bode, L. (2012). Facebooking it to the polls: A study in online social networking and political behavior. Journal of Information Technology \& Politics, 9(4), 352-369.

De Sio, L., Franklin, M., \& Russo, L. (Eds.) (2019). The European Parliament Elections of 2019. Roma: Luiss University Press.

Gerodimos, R., \& Justinussen, J. (2015). Obama's 2012 Facebook campaign: Political communication in the age of the Like button. Journal of Information Technology \& Politics, 12(2), 113-132.

Higuchi, K. (2016, March 16). KH Coder 3 Reference Manual. Retrieved Septhember 9, 2019, from https://khcoder.net/en/manual_en_v3.pdf adresinden alındı.

Himelboim, I., Lariscy, R. W., Tinkham, S. F., \& Sweetser, K. (2012). Social media and online political communication: The role of interpersonal informational trust and openness. Journal of Broadcasting \& Electronic Media, 56(1), 92-115.

Hix, S., \& Marsh, M. (2007, May). Punishment or protest? Understanding European Parliament elections. The Journal of Politics, 69(2), 495-510.

Hoffmann, C., \& Suphan, A. (2016). Stuck with 'electronic brochures'? How boundary management strategies shape politicians' social media use. Communication \& Society, 20, 551-569.

IRES (2019, May 30). Cine sunt votanții la scrutinele din 26 mai 2019. Profil politic. IRES. Retrieved February 2, 2020, from http://www.ires.com.ro/articol/369/cine-sunt-votan-ii-la-scrutinele-din26-mai-2019.-profiling-politic adresinden alındı.

Jost, J. T., Tucker, J., \& Bonneau, R. (2015). Tweeting from left to right: Is online political communication more than an echo chamber? Psychological Science, 26(10), 1531-1542.

Kemp, S. (2019). The global state of digital in 2019. Hootsiuite. Retrieved February 2, 2020, from https://hootsuite.com/resources/digital-in-2019 adresinden alınd1.

Kousser, T. (2004). Retrospective voting and strategic behavior in European Parliament elections. Electoral Studies, 23(1), 1-21.

Norris, P. (2003). Preaching to the converted? Pluralism, participation, and party websites. Party Politics, 9(1), 21-45.

Norris, P., \& Curtice, J. (2008). Getting the message out: A two-step model of the role of the internet in campaign communication flows during the 2005 British general election. Journal of Information Technology \& Politics, 4, 3-13.

Rafter, K. (2017). Background to the 2014 elections. In C. Holtz-Bacha, E. Novelli, \& K. Rafter (Eds.), Political Advertising in the 2014 European Parliament Elections (pp. 17-25). London: Palgrave Macmillan.

Reif, K., \& Schmitt, H. (1980). Nine second-order national elections - a conceptual framework for the analysis of European election results. European Journal of Political Research, 8(1), 3-44.

Stieglitz, S., \& Dang-Xuan, L. (2013). Social media and political communication: A social media analytics framework. Social Network Analysis and Mining, 3(4), 1277-1291.

Stier, S., Bleier, A., Lietz, H., \& Strohmaier, M. (2018). Election campaigning on social media: Politicians, audiences, and the mediation of political. Political Communication, 35(1), 50-74.

Stinson, L. (2016, February 26). Facebook reactions, the totally redesigned like button, is here. WIRED. Retrieved February 2, 2020, from https://www.wired.com/2016/02/facebook-reactions-totallyredesigned-like-button/ adresinden alındı. 
Strömbäck, J., Maier, M., \& Kaid, L. (2011). Political communication and election campaigns for the European Parliament. In J. Strömbäck, M. Maier, \& L. L. Kaid (Eds.), Political Communication in European Parliamentary Elections (pp. 3-16). Farnham-Burlington: Ashgate Publishing Ltd.

Ștefănel, A. (2016). Perspectives on the Romanian electoral context and media coverage of campaign discourses. In R. Boicu, S. Branea, \& A. Stefanel (Eds.), Political Communication and European Parliamentary Elections in Times of Crisis: Perspectives from Central and South-Eastern Europe (pp. 69-80). London: Palgrave Macmillan.

Vaccari, C. (2013). From echo chamber to persuasive device? Rethinking the role of the Internet in campaigns. New Media \& Society, 15(1), 109-127.

\section{APPENDIX}

\begin{tabular}{|c|c|c|c|c|c|c|c|c|c|}
\hline \multirow{2}{*}{ Page } & \multirow{2}{*}{$\begin{array}{l}\text { Page } \\
\text { likes }\end{array}$} & \multirow{2}{*}{$\begin{array}{c}\text { Page } \\
\text { popularity }\end{array}$} & \multicolumn{5}{|c|}{ Number of posts } & \multirow{2}{*}{$\begin{array}{l}\text { Date of } \\
\text { page } \\
\text { creation }\end{array}$} & \multirow{2}{*}{ Affiliation } \\
\hline & & & total & S1 & S2 & S3 & S4 & & \\
\hline \multicolumn{10}{|l|}{ Parties } \\
\hline PSD & 87,249 & 69.16 & 39 & 2 & 37 & 0 & 0 & $07 / 10 / 13$ & - \\
\hline PNL & 304,414 & 66.21 & 274 & 6 & 138 & 116 & 14 & $05 / 03 / 11$ & - \\
\hline $\begin{array}{l}\text { Alianța } 2020 \\
\text { USR PLUS }\end{array}$ & 65,619 & 67.02 & 224 & 11 & 180 & 27 & 6 & $02 / 03 / 19$ & - \\
\hline ALDE & 53,241 & 25.49 & 191 & 5 & 180 & 5 & 1 & $06 / 17 / 15$ & - \\
\hline PRO România & 19,955 & 8.53 & 174 & 2 & 158 & 3 & 11 & $06 / 13 / 18$ & - \\
\hline PMP & 48,652 & 27.36 & 102 & 5 & 87 & 4 & 6 & $08 / 05 / 13$ & - \\
\hline \multicolumn{10}{|l|}{ Party leaders } \\
\hline Liviu Dragnea & 173,909 & 181.09 & 21 & 0 & 21 & 0 & 0 & $04 / 25 / 12$ & PSD \\
\hline Ludovic Orban & 5,810 & 6.45 & 115 & 0 & 107 & 5 & 3 & $07 / 08 / 17$ & PNL \\
\hline Dan Barna & 70,655 & 57.77 & 71 & 6 & 53 & 6 & 6 & $11 / 02 / 16$ & $\begin{array}{l}\text { Alianța } \\
2020\end{array}$ \\
\hline Dacian Cioloș & 403,616 & 186.52 & 62 & 5 & 49 & 6 & 2 & $04 / 09 / 10$ & $\begin{array}{c}\text { Alianța } \\
2020\end{array}$ \\
\hline $\begin{array}{l}\text { Călin Popescu } \\
\text { Tăriceanu }\end{array}$ & 100,649 & 63.31 & 35 & 1 & 32 & 2 & 0 & $05 / 18 / 11$ & ALDE \\
\hline Victor Ponta & 794,638 & 34.94 & 99 & 2 & 86 & 5 & 6 & $09 / 27 / 10$ & $\begin{array}{c}\text { PRO } \\
\text { România }\end{array}$ \\
\hline Traian Băsescu & 439,526 & 120.78 & 38 & 2 & 31 & 3 & 2 & $01 / 16 / 12$ & PMP \\
\hline \multicolumn{10}{|l|}{ Candidates } \\
\hline Rovana Plumb & 32,785 & 11.25 & 27 & 2 & 24 & 1 & 0 & $01 / 24 / 11$ & PSD \\
\hline Carmen Avram & 39,743 & 46.29 & 46 & 3 & 43 & 0 & 0 & $04 / 22 / 13$ & PSD \\
\hline
\end{tabular}


Flavia Țăran, Alexandra Catalina Ormenișan

\begin{tabular}{|c|c|c|c|c|c|c|c|c|c|}
\hline Claudiu Manda & 43,771 & 47.29 & 159 & 0 & 157 & 1 & 1 & $02 / 17 / 11$ & PSD \\
\hline Rareș Bogdan & 244,269 & 44.26 & 224 & 7 & 177 & 29 & 11 & $10 / 14 / 11$ & PNL \\
\hline Mircea Hava & 11,906 & 12.11 & 14 & 0 & 12 & 1 & 1 & $04 / 11 / 12$ & PNL \\
\hline $\begin{array}{l}\text { Siegfried } \\
\text { Mureșan }\end{array}$ & 214,278 & 27.11 & 265 & 7 & 218 & 30 & 10 & $06 / 19 / 14$ & PNL \\
\hline $\begin{array}{l}\text { Cristian } \\
\text { Ghinea }\end{array}$ & 58,103 & 19.63 & 62 & 4 & 49 & 7 & 2 & $04 / 17 / 12$ & $\begin{array}{c}\text { Alianța } \\
2020\end{array}$ \\
\hline Dragos Pislaru & 10,738 & 14.30 & 72 & 2 & 61 & 8 & 1 & $01 / 20 / 17$ & $\begin{array}{c}\text { Alianța } \\
2020\end{array}$ \\
\hline $\begin{array}{l}\text { Clotilde } \\
\text { Armand }\end{array}$ & 108,699 & 36.86 & 128 & 5 & 80 & 33 & 10 & $04 / 01 / 16$ & $\begin{array}{c}\text { Alianța } \\
2020\end{array}$ \\
\hline Norica Nicolai & 90,806 & 12.90 & 99 & 3 & 92 & 3 & 1 & $05 / 07 / 10$ & ALDE \\
\hline Daniel Barbu & 69 & 0.28 & 5 & 0 & 5 & 0 & 0 & $04 / 22 / 19$ & ALDE \\
\hline $\begin{array}{l}\text { Varujan } \\
\text { Vosganian }\end{array}$ & 1,803 & - & 0 & 0 & 0 & 0 & 0 & $12 / 05 / 14$ & ALDE \\
\hline Corina Crețu & 61,267 & 19.46 & 119 & 4 & 112 & 2 & 1 & $09 / 05 / 13$ & $\begin{array}{c}\text { PRO } \\
\text { România }\end{array}$ \\
\hline Mihai Tudose & 23,153 & 32.46 & 20 & 2 & 13 & 5 & 0 & $07 / 06 / 17$ & $\begin{array}{c}\text { PRO } \\
\text { România }\end{array}$ \\
\hline Iurie Leancă & 50,216 & 14.85 & 20 & 2 & 15 & 2 & 1 & $06 / 03 / 13$ & $\begin{array}{c}\text { PRO } \\
\text { România }\end{array}$ \\
\hline Eugen Tomac & 57,307 & 24.99 & 41 & 3 & 31 & 5 & 2 & $10 / 03 / 12$ & PMP \\
\hline Marius Pașcan & 5,058 & 3.84 & 86 & 3 & 67 & 13 & 3 & $05 / 20 / 13$ & PMP \\
\hline Simona Vlădica & 2,964 & 2.77 & 109 & 4 & 102 & 1 & 2 & $10 / 25 / 16$ & PMP \\
\hline
\end{tabular}

DS1 = 31 Facebook pages

Source: Authors. 